\title{
Influence of the methodology on the formation of zeolite membranes MCM-22 for the oil/water emulsion separation
}

\section{(Influência da metodologia sobre a formação das membranas zeolíticas MCM-22 para a separação emulsão óleo/água)}

\author{
A.S. Barbosa ${ }^{1 *}, A . S$. Barbosa $^{1}$, M. G. F. Rodrigues ${ }^{1}$ \\ ${ }^{1}$ Universidade Federal de Campina Grande, Unidade Acadêmica de Engenharia Química, Av. Aprígio Veloso \\ 882, 58429-970, Campina Grande, PB, Brazil
}

\begin{abstract}
This work aimed to produce zeolite membranes MCM-22 using two methods of synthesis, dip coating (DC) and vapor phase transport (VPT), to be evaluated in the oil/water emulsion separation process. The membranes were prepared at $150{ }^{\circ} \mathrm{C}$ for 10 days and characterized by X-ray diffraction and scanning electron microscopy. They were evaluated in tests of pure water permeation and oil/water emulsion separation system of a synthetic effluent, using a stainless-steel module under the conditions of the initial concentration of the emulsion of $100 \mathrm{mg} / \mathrm{L}$, temperature of $25{ }^{\circ} \mathrm{C}$ and pressure of 2.0 bar. The results showed that the MCM-22 zeolite membrane by DC had the final value of the permeate concentration of $3.2 \mathrm{mg} / \mathrm{L}$ and the membrane prepared by VPT presented a final value of $3.9 \mathrm{mg} / \mathrm{L}$ which were within the standards required by Resolution No. 392 of CONAMA which is up to $20 \mathrm{mg} / \mathrm{L}$ of mineral oils.
\end{abstract}

Keywords: MCM-22, zeolite membranes, synthesis dip coating, vapor-phase transport, emulsion oil-water separation.

Resumo

Esse trabalho teve por objetivo produzir membranas zeolíticas MCM-22 utilizando dois métodos distintos de síntese, dip coating (DC) e transporte em fase vapor (VPT), para serem avaliadas no processo de separação emulsão óleo/água. As membranas foram preparadas a $150{ }^{\circ} \mathrm{C}$ por 10 dias, caracterizadas por difração de raios X e microscopia eletrônica de varredura e avaliadas em testes de permeação de água pura e testes de separação emulsão óleo/água de um efluente sintético, utilizando um módulo de aço inoxidável nas condições de concentração inicial da emulsão de $100 \mathrm{mg} / \mathrm{L}$, temperatura de $25{ }^{\circ} \mathrm{C}$ e pressão de 2,0 bar. Os resultados mostraram que a membrana zeolítica MCM-22 por DC teve valor final da concentração no permeado de 3,2 mg/L e a membrana preparada por VPT apresentou valor final de 3,9 $\mathrm{mg} / \mathrm{L}$, que foram dentro dos padrões exigidos pela Resolução $n^{\circ} 392$ do CONAMA que é de até $20 \mathrm{mg} / \mathrm{L}$ de óleos minerais.

Palavras-chave: MCM-22, membranas zeolíticas, sínteses dip coating, transporte em fase vapor, separação emulsão óleo/água.

\section{INTRODUCTION}

The large volume of industrially-produced oily wastewater has resulted in alarming levels of environmental pollution and resource usage problems. A wide range of conventional and emerging approaches has been established that can effectively reduce these pollutants to an acceptable level so that the treated wastewater can be discharged for reuse [1]. Oily wastewater pollution generally consists of the following aspects: affects drinking water and groundwater resources, endangers aquatic resources, endangers human health, pollutes the atmosphere, affects crop production, destroys the natural landscape, all occurring most likely because of the accumulation of this oily residue [2]. Membrane filtration is a highly desirable solution for removing oil from oily wastewater because of its advantages

*antoniellybarbosa@yahoo.com.br

(D) https://orcid.org/0000-0002-5739-8772 of energy efficiency, easy processing, and low maintenance costs [3]. Membranes consist of a barrier that separates two phases and which totally or partially restricts the transport of one or several chemical species in the phases [4]. Synthetic membranes can be fabricated from polymeric materials as well as ceramic materials. Membrane restricts the transport of particulate matter, colloidal and chemical species dissolved in organic solvents or water [4]. Selective transport is performed based on the differences in the physical and/ or chemical characteristics of the components permeating through the membrane. In recent years, membrane processes are widely used in the textile, pharmaceutical, cellulose, semiconductor, leather tanning, mining, electroplating, dairy, food processing and beverage industries [5, 6]. The processes of separation by membranes have advantages due to their low costs in long-term operational terms due to their chemical and thermal stability, energy savings and selectivity [7]. The processes that utilize membranes in the separation are effective compared to conventional distillation 
and adsorption processes $[8,9]$. Ceramic membranes are also known as inorganic membranes, which are formed by a layer or multilayer of ceramic materials on the matrix. The main materials include alumina $\left(\mathrm{Al}_{2} \mathrm{O}_{3}\right)$, zirconia $\left(\mathrm{ZrO}_{2}\right)$, titanium oxide $\left(\mathrm{TiO}_{2}\right)$, silicon oxide $\left(\mathrm{SiO}_{2}\right)$, etc. [10]. They exhibit various advantages, such as high thermal, chemical and mechanical stability and do not expand easily, but also present some disadvantages, such as high production cost. These membranes can be used in a wide variety of applications and, at the same time, have high selectivity and permeability [11].

Zeolite membranes constitute a class of microporous inorganic membranes where zeolite crystals grow in continuous film form on a commercially available meso or macroporous carrier (alumina, titania or stainless steel) of flat or tubular geometry that provides mechanical resistance to the membrane. These membranes are an alternative in terms of separation of mixtures of species that exhibit differences in size or adsorption properties because the separation of such blends is difficult to perform using polymer membranes or other separation operations [1216]. The zeolite membranes have attracted a great deal of attention because the pore size is well defined and have chemical and thermal stabilities. Several types of zeolites deposited on porous inorganic supports (zeolite membranes) have been studied for the molecular separation of gas and liquid mixtures. The separation in the zeolite membranes is governed by competitive adsorption, diffusion and size exclusion mechanisms [17-37]. The zeolite membranes are obtained by several methods, among them the in situ method, with one or more zeolite layers, is highlighted, and the secondary growth, with seed support coverage followed by hydrothermal synthesis: dip coating and vaporphase transport [38]. In the in situ method, the surface of the support is placed in direct contact with the solution containing the zeolite precursors and then subjected to hydrothermal conditions and autogenous pressure. Under suitable conditions, nucleation of the zeolite crystals occurs on the support, followed by its growth, to form the zeolite layer. At the same time that reactions occur in solution, also the deposition of the nuclei and crystals on the surface, followed by its incorporation in the membrane [39]. The most promising method for formation of zeolite membranes is the secondary growth method, which is intended to cover the surface of the support with a layer of zeolite seeds [40]. Subsequently, a hydrothermal treatment is performed on the seeded carrier to promote the growth of the crystals. This methodology increases the rate of crystallization, avoiding the nucleation step. The vapor transport method is a procedure in which a layer of the synthesis reaction mixture is deposited on the carrier and then this mixture is transformed into zeolite in the presence of vapors. It is an alternative to prevent the growth of crystals that may impair the final quality of the zeolite membrane [41].

The MCM-22 zeolite was originally synthesized by Mobil researchers in 1990 [42]. From a structural point of view, MCM-22 is characterized by a complex porosity, containing both medium and large pores [43]. The structure of the MCM-22 zeolite (IZA structure, code MWW) consists of two independent pores systems [44], one of which is defined by two-dimensional sinusoidal 10 -membered-ring (MR) channels $(0.40 \times 0.50 \mathrm{~nm})$. The second pore system consists of large supercages with a free inner diameter of $0.71 \mathrm{~nm}$ which is circumscribed by 12 -membered rings. The height of the large supercages is $1.82 \mathrm{~nm}$. These huge intracrystalline voids are accessible only through 10 -membered-ring apertures $(0.40 \times 0.55 \mathrm{~nm})[45,46]$. It is currently considered that the MCM-22 zeolite crystallizes in the form of a precursor containing a system comprising large external cages with 12 members, deemed 'cups' $(0.71 \times 0.70$ $\mathrm{nm})$, unlike a system of 10 -membered sinusoidal channels [47]. The MWW structure can be built using units of 36T atoms $(\mathrm{T}=\mathrm{Si}$ or $\mathrm{Al})$. The T36-unit resembles a 'half-cage' (or 12-ring cup) consisting of cylindrical 6-ring band closed at one side by a 6-ring, to which two T2-dimers and two $\mathrm{T}$ atoms are bonded (or built from four 6-1 units and one 1-6-1 unit) [48]. The one-dimensional periodic building unit is obtained when T36-units, related by a mirror plane perpendicular to ' $a$ ', are connected into columns along ' $c$ ' through double 6-ring and single T-T bonds. Liu et al. [41] studied the MFI-type zeolite prepared on a porous stainlesssteel screen using the in situ secondary growth method. In order to obtain better oil/water separation performance, $\mathrm{Al}^{3+}$ ions were introduced into the zeolite structure to control the hydrophilicity of the zeolite coated mesh. As the aluminum content increased, the contact angle measurement showed that the membrane hydrophilicity increased from $136.8^{\circ}$ to $163.5^{\circ}$. The oil rejection rate reached a value greater than 99\% for the membrane. Fifteen successive cycles were used and the membrane showed high chemical stability. Oil rejection rates were greater than $96 \%$ for all oils.

There are urgent issues due to the growth of industrial oily wastewater as well as frequent accidents with oil spills. Within this context, Wen et al. [49] have observed that the use of membranes for oil/water separation is an alternative to these problems. Membrane-based materials with special hydrophilicity are therefore desired for separating oil/water. However, it remains a challenge to manufacture stable and energy-efficient membranes suitable for oil/water separation. Zeolite membranes have attracted great interest in the research because of their advantages of unique pore character, excellent chemical, thermal and mechanical stability, etc. In this work, a study was carried out on the production of zeolite coated films for application in the oil/water separation process by gravity. The high separation efficiencies for various oils can be achieved based on the excellent super hydrophilicity and superoleophobicity characteristics of the zeolite surface. More importantly, these films are resistant to corrosion in the presence of corrosive media, which makes them promising for application in the oil/water separation process. This work is part of a line of research developed at the Laboratory of Development of New Materials-LABNOV of the UFCG. This line of research covered a series of studies on the synthesis of zeolite membranes in the oil/water 
emulsion separation process [50-65]. This study is an integral part of this line of research and proposes the development of efficient membranes for the oil/water emulsion separation process. The literature on the application of MCM-22 zeolite membrane to the oil/water emulsion separation process is still scarce, so the main objective of this work was to evaluate the behavior of the separation process oil/water emulsion by zeolite membranes prepared by two different methodologies of synthesis, secondary growth method - dip coating, and vapor-phase transport.

\section{MATERIALS AND METHODS}

Synthesis of the ceramic membrane ( $\alpha$-alumina): calcined alumina A1000 SG (Almatis) was used for the synthesis of ceramic ( $\alpha$-alumina) support. A dispersion of $200 \mathrm{~mL}$ with the following composition (wt $\%$ ) was prepared: $40 \%$ alumina; $0.2 \%$ PABA, para-amino benzoic acid (dissolved in ethanol); $0.5 \%$ oleic acid (lubricant); and 59.3\% ethyl alcohol. The mixture was ground for $1 \mathrm{~h}$ in a ball mill, dried in an oven for $24 \mathrm{~h}$ at $60{ }^{\circ} \mathrm{C}$, and then humidified with $7 \%$ water, resting for one day. $3 \mathrm{~g}$ of the material was weighed and placed in the mold. The pressing was performed with 4 ton. The compressed material was submitted to sintering at $1200{ }^{\circ} \mathrm{C}$ for $1 \mathrm{~h}$. It was obtained a ceramic flat membrane $(\alpha$-alumina $)$ with the dimensions: diameter $26.6 \mathrm{~mm}$ and thickness of $3.6 \mathrm{~mm}$ [59].

MCM-22 zeolite preparation: the MCM-22 zeolite was prepared by thermal treatment of a specific aluminosilicate precursor. This precursor was obtained according to the following procedure: $3.11 \mathrm{~g}$ of anhydrous sodium aluminate (50-56\% $\mathrm{Al}_{2} \mathrm{O}_{3}, 40-45 \% \mathrm{Na}_{2} \mathrm{O}$, Riedel-de Haën) and $1.93 \mathrm{~g}$ of sodium hydroxide ( $97 \%$ Merck) were dissolved in 415 $\mathrm{g}$ of deionized water. The obtained solution was stirred for $15 \mathrm{~min}$. Then, $25.4 \mathrm{~g}$ of hexamethyleneimine (HMI) (99\% Aldrich) was added dropwise under vigorous stirring, and $30.7 \mathrm{~g}$ of silica (Aerosil 200, Degussa) was added to the mixture and the slurry was vigorously stirred for additional $30 \mathrm{~min}$. After that, the gel was transferred to an autoclave and heated at $150{ }^{\circ} \mathrm{C}$ for 10 days, without stirring, under static condition. Then, the autoclave was quenched in cold water, and the obtained material was washed with deionized water, centrifuged until a $\mathrm{pH} \leq 9$, and dried at $60^{\circ} \mathrm{C}$. In this step, the obtained material presented a layered structure, being signed as MCM-22 [65].

Synthesis of zeolitemembranes. Secondary growthmethod - dip coating: the seed of MCM-22 zeolite synthesized in the laboratory, as described above, was used. The procedure used to obtain the MCM-22 zeolite membrane was the secondary growth method - dip coating, which consisted of impregnating zeolite crystals on the surface of the ceramic membrane, using an MCM-22 zeolite dispersion. In this method the surface of the ceramic membrane was seeded by dip coating using an ethanol dispersion containing $5 \%$ of MCM-22 zeolite seeds. The membrane was dipped into this dispersion remaining for a period of $1 \mathrm{~min}$ and then dried at $60{ }^{\circ} \mathrm{C}$. This procedure was repeated three times.
The membrane seeded with zeolite MCM-22 was placed in teflon crucible containing the MCM-22 zeolite synthesis gel, which was inserted in a stainless-steel autoclave and taken to the oven at $150{ }^{\circ} \mathrm{C}$, starting the hydrothermal treatment for a period of 10 days. The obtained synthesis products were washed with distilled water to neutral $\mathrm{pH}$ and oven-dried at $60{ }^{\circ} \mathrm{C}$ for $24 \mathrm{~h}$. The nomenclature used for the zeolite membrane obtained from the dip coating method was ZMDC. Vapor phase transport: in this method, a quantity of MCM-22 zeolite synthesis gel was deposited on the surface of the ceramic membrane, which was placed in a teflon crucible cast inside a teflon crucible containing the zeolite synthesis gel MCM-22. The set (teflon crucible cast and teflon crucible) was placed in a stainless-steel autoclave and taken to the oven at $150{ }^{\circ} \mathrm{C}$, starting the hydrothermal treatment for a period of 10 days. The obtained synthesis products, MCM-22 zeolite membranes, were washed with distilled water to neutral $\mathrm{pH}$ and oven-dried at $60{ }^{\circ} \mathrm{C}$ for $24 \mathrm{~h}$. The nomenclature used for the zeolite membrane obtained from the steam transport method was ZMVPT.

Characterization. X-ray diffraction $(X R D)$ : the powder method was used, in which the samples were sieved in an ABNT No. $200(0.074 \mathrm{~mm})$ sieve and then placed in an aluminum specimen holder for XRD, using a Shimadzu XRD 6000 equipment. Operational details of the technique have been set as follows: copper $\mathrm{K} \alpha$ radiation at $40 \mathrm{kV} / 30$ $\mathrm{mA}$, with a goniometer velocity of $2^{\circ} \cdot \mathrm{min}^{-1}$ and a step of $0.02^{\circ}$ in the range of $2 \theta$ scanning from $2^{\circ}$ to $50^{\circ}$. The only $\mathrm{d}$-spacing of interest in the X-ray patterns was the basal spacing along the c axis. Scanning electron microscopy (SEM): the samples were covered with a thin layer of gold, due to the high electron conductivity of this metal, fixed in the aluminum specimen holder by an adhesive carbon tape. The micrographs used to analyze the morphology of the samples were obtained through a scanning electron microscope Philips XL 30 EDAX, equipped with an X-ray energy dispersive spectrometer. Bubble point: the bubble point method provided information about the pores that control the permeation. This method was used to measure pores with size above $50 \mathrm{~nm}$ following the ASTM F316-03 standard. It consisted of filling the porous structure of the membrane with a liquid and measuring the air pressure necessary to displace the liquid inside the pores. The minimum pressure necessary to blow the first observed air bubble corresponded to the largest pore size of the membrane; this value is known as the bubble point. The mathematical relationship between pressure and pore size is given by Washburn equation:

$$
\Delta \mathrm{P}=\frac{4 \gamma \cos \varphi}{\mathrm{d}_{\mathrm{p}}}
$$

where $\Delta \mathrm{P}$ is the pressure drop (bar), $\mathrm{d}_{\mathrm{P}}$ is the pore size $(\mu \mathrm{m})$, $\phi$ is the contact angle between the fluid and pore walls and $\gamma$ is the liquid surface stress (isopropyl alcohol). In order to be able to use the Washburn equation, the pores were assumed cylindrical. In order to reduce surface tension and facilitate measurement, liquids with lower surface tension are used, such as alcohols. 
Evaluation of membranes. Measurement of pure water flow: Fig. 1 shows the system used in the process of water flow measurements. The components were: I) water (L); II) peristaltic pump (Masterflex) with a flow rate of $0.002 \mathrm{~L} / \mathrm{min}$; and III) membrane permeation module. The permeate samples were run at 10 min intervals for a total period of $60 \mathrm{~min}$ for each membrane. Separation of oil/water emulsion: membranes were evaluated in the oil/water separation process using the system shown in Fig. 1. The evaluation conditions were: initial concentration of oil/water emulsion of $100 \mathrm{mg} / \mathrm{L}$, temperature of $25^{\circ} \mathrm{C}$ and pressure of $2.0 \mathrm{bar}$. The process was evaluated during a time period of $1 \mathrm{~h}$. The membranes were recycled only once. Preparation of the oil/water emulsion: the emulsion was prepared using distilled water and Lubrax SL SAE 20W/50 API SL automotive lubricating oil. An oil/water emulsion having a concentration of $100 \mathrm{mg} / \mathrm{L}$ was prepared by stirring at a rate of $17000 \mathrm{rpm}$ for $20 \mathrm{~min}$. Determination of oil and grease concentrations: the concentration of oil present in the aqueous phase was determined by analysis of absorbance using a spectrophotometer (UVvisible, UV 1800, Shimadzu). A calibration curve of absorbance versus concentration was constructed using different known concentrations of oil ranging from 0 to $100 \mathrm{ppm}$ with a coefficient of determination $\left(\mathrm{R}^{2}\right)$ equal to 0.9974. Chloroform was used as a solvent for extraction, because of excellent response (significant peak) at a wavelength of $262 \mathrm{~nm}$ for the samples analyzed. The absorbance at this wavelength is commonly used to estimate the concentration of oil in water samples [66] and also in water produced. This wavelength is used to measure the bands of aromatic $\mathrm{CH}$ in the medium. This implementation procedure was designed to standardize the determination of oil and grease. Technical procedure: in the process of extracting the remaining oil there are some important variables, such as amount of solvent, stirring time and number of extraction steps. According to [67], this method was standardized and the solvent/volume ratio of the sample was found to be $1: 1$, stirring time of $5 \mathrm{~min}$ and a single extraction step was sufficient to extract the oil from the sample. To determine the amount of oil present in the water, the technique consisted of collecting $5 \mathrm{~mL}$ of the sample to be analyzed and adding $5 \mathrm{~mL}$ of chloroform. The solvent phase (chloroform+oil) was collected with the aid of a syringe for 5 min and after separation from the phase. The absorbance was read at $262 \mathrm{~nm}$ in the spectrophotometer and using the calibration curve it was possible to determine the oil concentration in the sample. The oil flow was obtained through:

$$
J=\frac{\mathrm{V}}{\Delta \mathrm{t} \cdot \mathrm{A}}
$$

where $\mathrm{J}$ is the water flux $\left(\mathrm{L} \cdot \mathrm{m}^{-2} \cdot \mathrm{h}^{-1}\right), \mathrm{V}$ is the permeate volume $(\mathrm{L}), \mathrm{A}$ is the membrane area $\left(\mathrm{m}^{2}\right)$ and $\Delta \mathrm{t}$ is the permeation time (h). The coefficient of rejection (R\%) was calculated from:

$$
\mathrm{R} \%=\frac{\mathrm{C}_{0}-\mathrm{C}_{\mathrm{f}}}{\mathrm{C}_{0}} .100
$$

where $\mathrm{C}_{0}$ is the oil concentration in the feed, and $\mathrm{C}_{\mathrm{f}}$ is the oil concentration in the permeate. Evaluation of the reuse of the ceramic membrane and MCM-22 zeolite membrane: the ceramic membrane and MCM-22 zeolite membrane were reused following the oil/water emulsion separation cycle. The membranes used in this first cycle were backwashed using neutral detergent in a continuous flow system for 60 min and then circulating distilled water to remove residual surfactant from the membrane. This period was sufficient to remove all residual material. The washed membranes were then oven-dried at $60{ }^{\circ} \mathrm{C}$ for $24 \mathrm{~h}$. The zeolite membranes were reused for a further $60 \mathrm{~min}$ permeation cycle in the oil/ water emulsion separation stream.

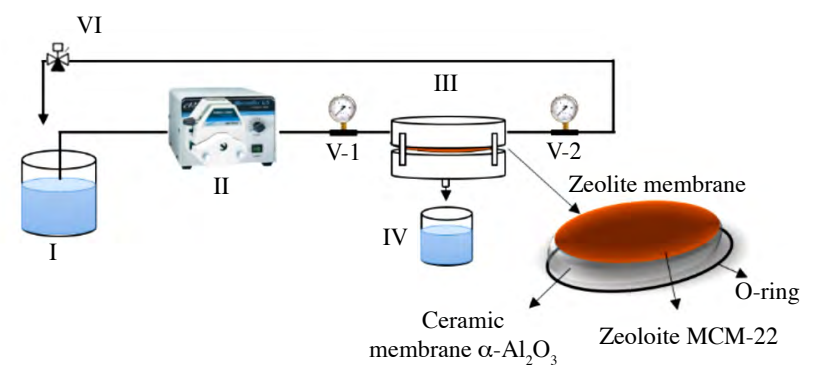

Figure 1: Permeation system used to evaluate the permeability of ceramic and zeolite membrane: I) feed tank; II) peristaltic pump; III) permeation/separation module (stainless-steel); IV) permeated volume; V-1) pressure gauge before module input; V-2) pressure gauge at the concentrate outlet; and VI) regulating valve (concentrate outlet).

[Figura 1: Sistema de permeação utilizado para avaliação da permeabilidade das membranas cerâmicas e zeoliticas: I) tanque de alimentação; II) bomba peristáltica; III) módulo de permeação/ separação (aço inoxidável); IV) volume permeado; V-1) manômetro antes da entrada do módulo; $V$-2) manômetro na saída do concentrado; e VI) válvula reguladora (saída de concentrado).]

\section{RESULTS AND DISCUSSION}

Secondary growth method - dip coating: Figs. $2 \mathrm{a}$ and $2 \mathrm{~b}$ show the XRD pattern and SEM micrograph of the zeolite membrane ZMDC. The analysis of the XRD pattern showed two distinct phases as the constituents of the zeolite membrane structure: MCM-22 and $\alpha$-alumina. The MCM-22 zeolite synthesized on the ceramic membrane ( $\alpha$-alumina) showed a crystalline structure as reported in [62-64], with no evidence of other crystalline phases (impurities). Fig. $2 b$ shows the SEM image for the zeolite membrane ZMDC, related to the active layer, and provides an example of an MCM-22 zeolite membrane. Two different morphologies were observed in this membrane. After a detailed examination of the cross-section (Fig. 2c), the membrane showed a layer composed of crystals of MCM-22 zeolite materials synthesized on the surface of the ceramic membrane ( $\alpha$-alumina) $[58,68]$. The morphology of the active layer (MCM-22 zeolite) formed on the surface of the ceramic support showed spherical regular aggregates 
[69]. From the image, the formation of an active layer (zeolite MCM-22) on the surface of the ceramic membrane was observed. SEM image of the cross-section of the MCM-22 zeolite membrane ZMDC showed a thickness of the active layer of the zeolite membrane of $26.7 \mu \mathrm{m}$ (Fig. 2c).

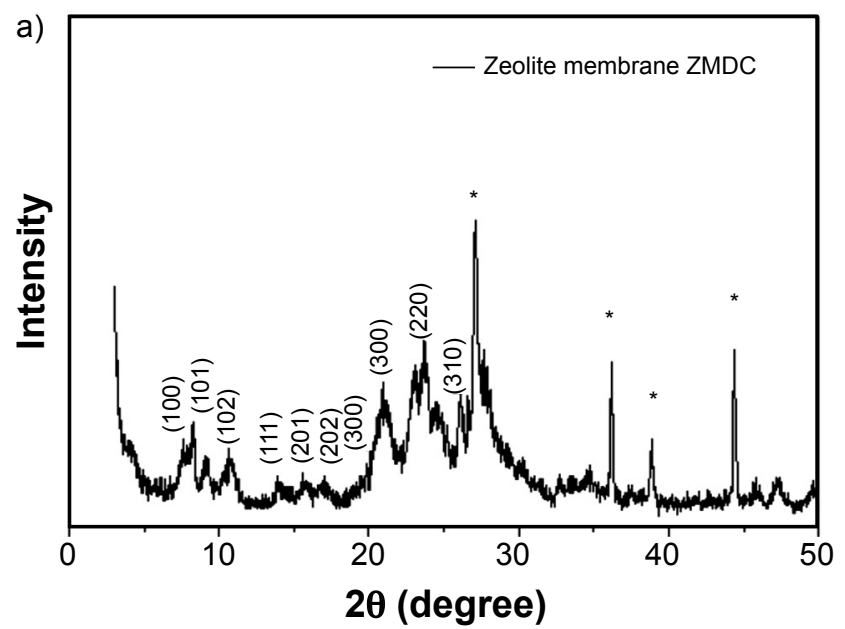

b)

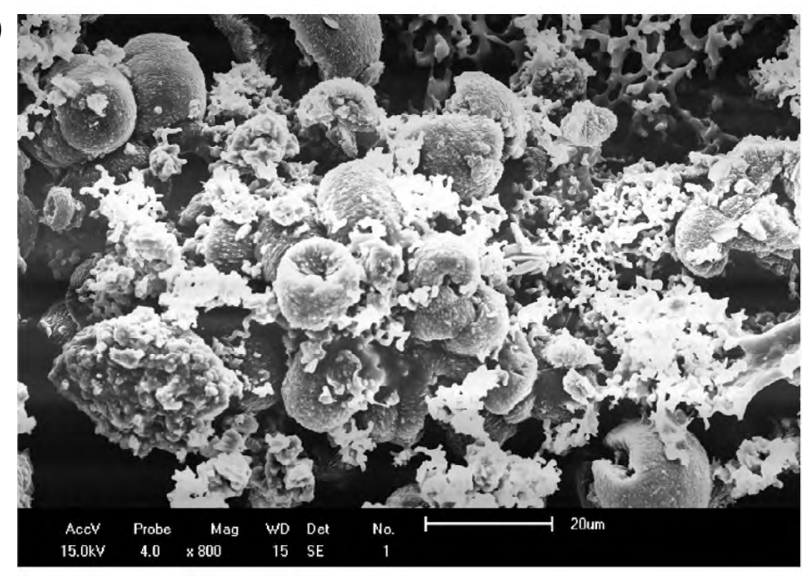

c)

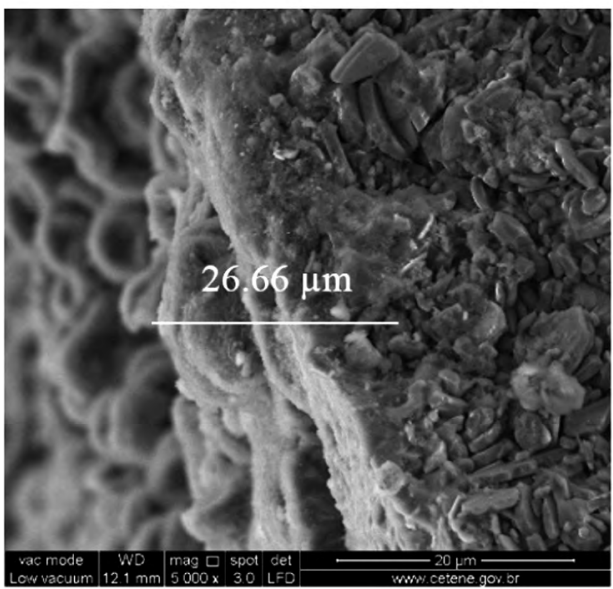

Figure 2: XRD pattern of ZMDC/ $\alpha$-alumina (* - $\alpha$-alumina) (a), and SEM micrographs of the active layer (b), and cross-sectional view (c) of MCM-22 zeolite membrane ZMDC.

[Figura 2: Difratograma de raios $X$ da membrana zeolítica MZDC/ $\alpha$-alumina (* - a-alumina) (a) e micrografias de MEV da camada ativa (b) e da seção transversal (c) da membrana zeolítica MCM-22 MZDC.]
Vapor phase transport method: Fig. 3a shows the XRD pattern of zeolite membrane ZMVPT. It was observed the crystalline phase of zeolite MCM-22, with characteristic peaks of the structure, in the intervals of $2 \theta=12-25^{\circ}$ and $26-29^{\circ}$. It was also possible to observe the formation of

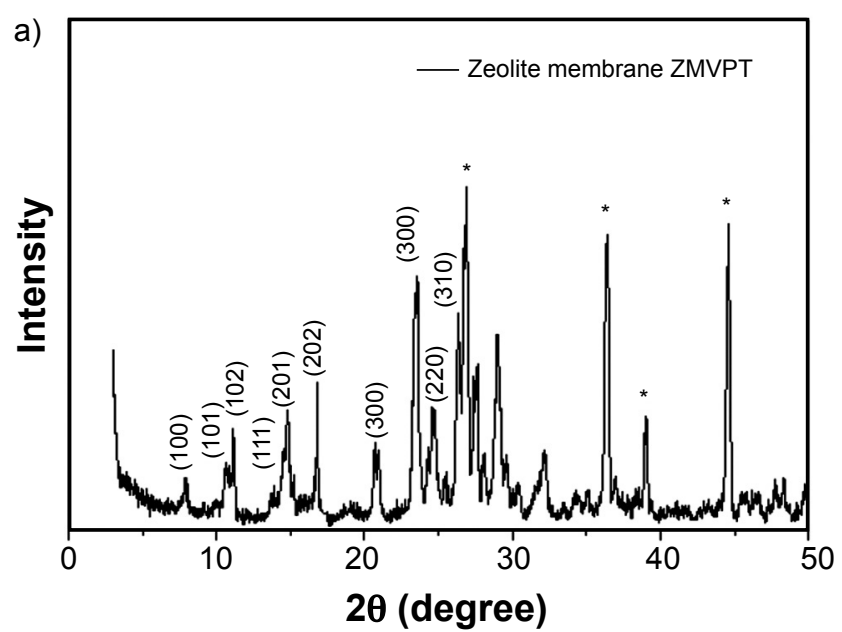

b)

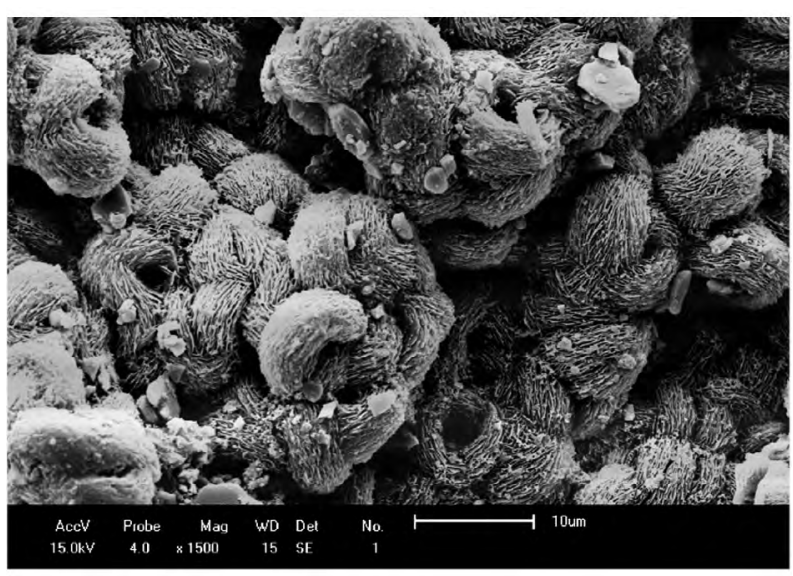

c)

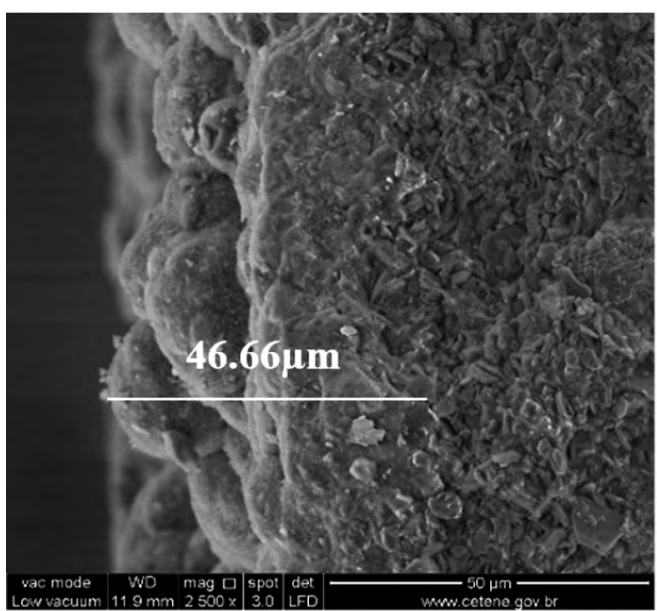

Figure 3: XRD pattern of ZMVPT/ $\alpha$-alumina (* - $\alpha$-alumina) (a), and SEM micrographs of the active layer (b), and cross-sectional view (c) of MCM-22 zeolite membrane ZMVPT.

[Figura 3: Difratograma de raios $X$ da membrana zeolítica ZMVPT/ $\alpha$-alumina (* - $\alpha$-alumina) (a) e micrografias de MEV da camada ativa (b) e da seção transversal (c) da membrana zeolítica MCM-22 MZVPT.] 
the characteristic peaks of $\alpha$-alumina, represented by *, confirming the formation of the MCM-22 zeolite membrane [58]. Fig. 3b shows the SEM image of the zeolite membrane ZMVPT; it was verified the formation of a homogeneous surface without cracks or superficial defects. It can be seen in the zeolite membrane ZMVPT that crystals with spherical shape were dispersed on the layer of the ceramic membrane ( $\alpha$-alumina), according to [59]. The SEM image of the crosssection of the MCM-22 zeolite membrane presented an active layer with a thickness of $46.7 \mu \mathrm{m}$ (Fig. 3c).

The bubble point technique is a well established, simple, and helpful tool for measuring the maximum trans-membrane pressure that a supported liquid membrane can withstand. In this technique, the pressure is moderately increased to one side of the membrane using a compressed gas such as air or nitrogen. When the liquid begins to empty out of the pores, gas bubbles can be detected on the permeating side of the membrane and the flow rate becomes non-zero [70, 71]. In this study, the bubble point method was used to determine the maximum pressure drop that can be withstood before expulsion of the liquid from the $\alpha$-alumina ceramic support and MCM-22 zeolite membrane. The results of the pore diameter values of the membranes calculated from Eq. A are listed in Table I. It was observed that the membrane of larger pore diameter predicted from the bubble point method corresponded to the $\alpha$-alumina ceramic support (3.32 $\mu \mathrm{m})$. The ceramic membrane ( $\alpha$-alumina) can be classified as a microfiltration membrane. When inserting the zeolitic layer, a decrease in the pore diameter was observed, considering that the MCM-22 zeolite had much smaller pores. The MCM-22 zeolite membranes required relatively much higher pressures to expel the first bubble, confirming the presence of a layer of resistance, corresponding to the layer of zeolite deposited on the support from the synthesis of the MCM22 zeolite, according with XRD and SEM characterization. This reduction in the pore diameter observed for the MCM22 zeolite membrane occurred due to deposition of the MCM-22 zeolite on the surface of the ceramic membrane forming the selective layer of the zeolite membrane, which presented a smaller pore diameter, thus presenting a larger removal potential in oil/water emulsions.

Table I - Bubble point of ceramic membrane ( $\alpha$-alumina) and MCM-22 zeolite membranes, ZMDC and ZMVPT.

[Tabela I - Ponto de bolha de membrana cerâmica ( $\alpha$-alumina) e membranas de zeólita MCM-22 MZDC e MZVPT.]

\begin{tabular}{lcc}
\hline Sample & $\Delta \mathrm{P}($ bar $)$ & $\mathrm{d}_{\mathrm{p}}(\mu \mathrm{m})$ \\
\hline Ceramic membrane $(\alpha$-alumina $)$ & 0.25 & 3.32 \\
Zeolite membrane ZMDC & 4.25 & 0.19 \\
Zeolite membrane ZMVPT & 4.75 & 0.18 \\
\hline
\end{tabular}

Measurements of pure water flow: to evaluate the performance and the presence of defects in the membranes, water flow characterization was used. It is always a key factor in membrane applications as it allows the treatment of large quantities of liquid at lower costs. The flow of pure water through the ceramic and zeolite membranes are shown in Fig. 4. The flow of pure water remained practically constant throughout the $60 \mathrm{~min}$. This behavior showed that the pure water flow of the ceramic membrane was influenced mainly by the porosity and pore size distribution. The pure water flow of asymmetric membranes is generally affected by pore size, and the porosity can subsequently increase the flow of pure water. The results of pure water flow (Fig. 4) for zeolite membranes ZMDC and ZMVPT had a lower mean flow (794 and $805 \mathrm{~L} . \mathrm{m}^{-2} \cdot \mathrm{h}^{-1}$, respectively), when compared to the ceramic membrane $\left(1000 \mathrm{~L} \cdot \mathrm{m}^{-2} \cdot \mathrm{h}^{-1}\right)$, suggesting that the zeolite layer MCM-22 inserted on the ceramic membrane had influence on the pore size of the zeolite membrane, evidencing that some properties were modified, such as pore size. This result was similar to that found in [52]; the authors used the ceramic and zeolite membranes $\mathrm{Y} / \alpha$-alumina (prepared by the dip coating method).

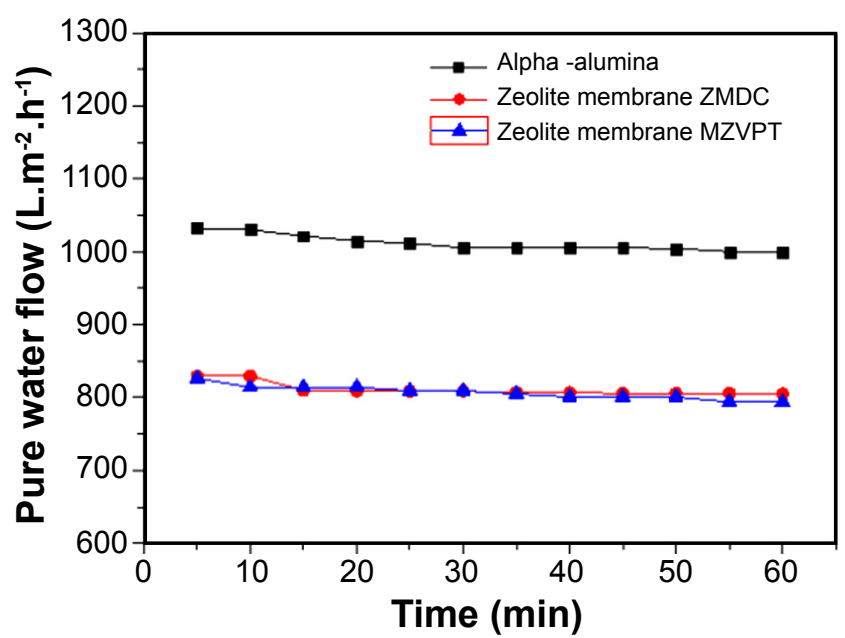

Figure 4: Permeate flow of pure water as a function of time for ceramic and zeolite (ZMDC and ZMVPT) membranes. Conditions: $\mathrm{P}=2.0$ bar, temperature $=25^{\circ} \mathrm{C}$, time $=60 \mathrm{~min}$.

[Figura 4: Fluxo permeado de água pura em função do tempo para as membranas cerâmica e zeolíticas (MZDC e MZVPT). Condições: $P=2,0$ bar, temperatura $=25^{\circ} \mathrm{C}$, tempo $\left.=60 \mathrm{~min}.\right]$

Separation of oil/water emulsion. Evaluation of ceramic and MCM-22 zeolite membranes ( $1^{\text {st }}$ cycle): Figs. 5a and $5 \mathrm{~b}$ shows the measurements of oil content in the permeate and rejection coefficient as a function of time for the $1^{\text {st }}$ cycle, obtained with oil/water emulsion with emulsion droplets ranging from 4.90 to $5.63 \mu \mathrm{m}$ in diameter, for the ceramic ( $\alpha$-alumina) and MCM-22 zeolite ZMDC and ZMVPT membranes prepared by the DC and VPT methods. The following observations were verified: 1) ceramic membrane: an initial decrease of the concentration of permeate oil from 100 to $25 \mathrm{mg} / \mathrm{L}$ in the first $5 \mathrm{~min}$ of operation was observed, remaining practically constant over time operation; the average remaining oil concentration was $15 \mathrm{mg} / \mathrm{L}$; the value of the rejection coefficient after $60 \mathrm{~min}$ of operation was $88.0 \%$; 2) zeolite membrane ZMDC: an initial reduction of the permeate oil concentration from 100 

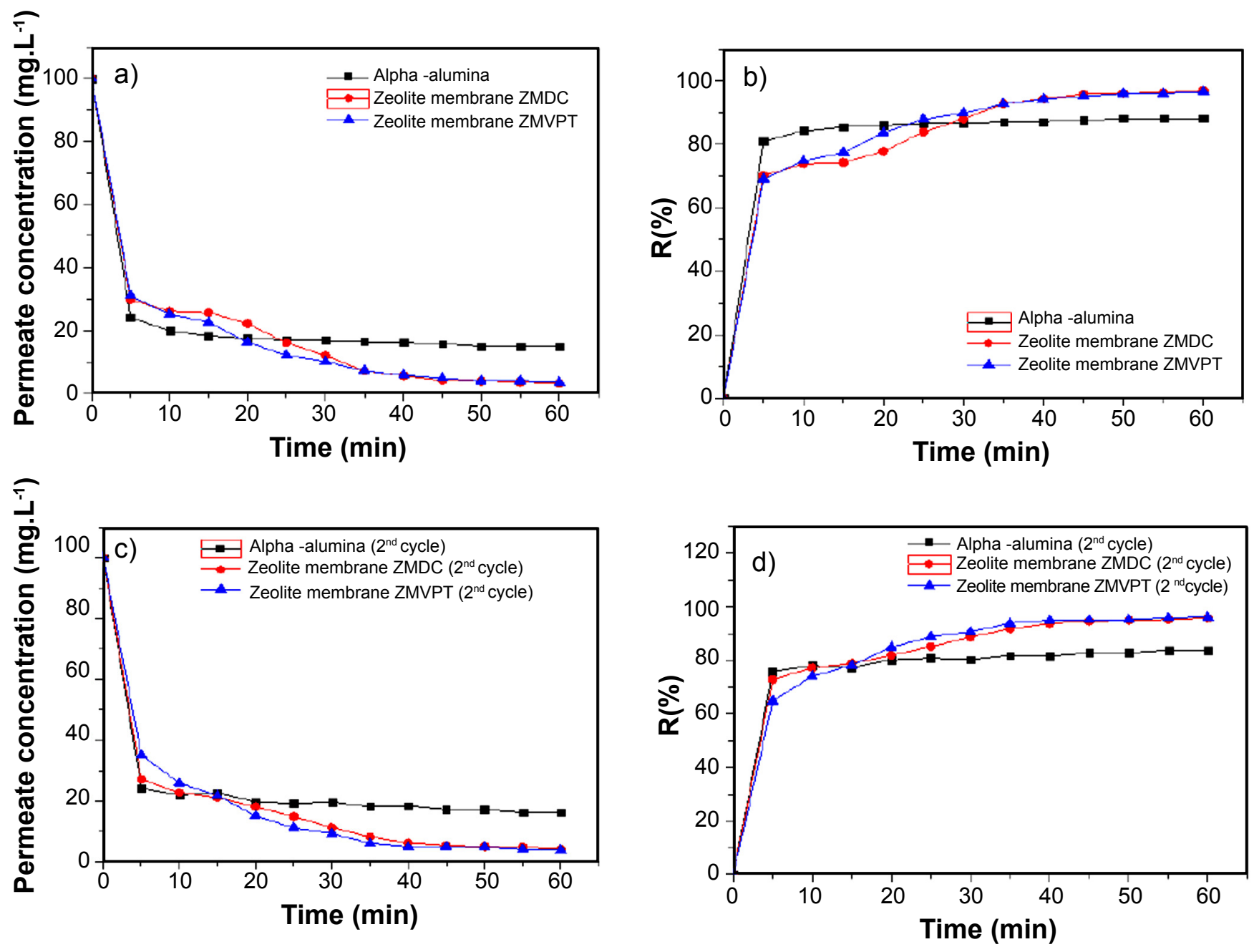

Figure 5: Permeate concentration (a,c) and oil rejection coefficient, R (b,d), of ceramic and zeolite (ZMDC and ZMVPT) membranes for the $1^{\text {st }}$ cycle $(\mathrm{a}, \mathrm{b})$ and $2^{\text {nd }}$ cycle $(\mathrm{c}, \mathrm{d})$.

[Figura 5: Concentração do permeado (a,c) e coeficiente de rejeição do óleo, $R(b, d)$, das membranas cerâmica e zeolíticas MZDC e MZVPT para o $1^{o}$ ciclo $(a, b)$ e $2^{o}$ ciclo $(c, d)$.]

to $24 \mathrm{mg} / \mathrm{L}$ was identified in the first $5 \mathrm{~min}$ of operation, then decreasing to $20 \mathrm{~min}$ and then remaining almost constant; the average remaining oil concentration was 3.2 $\mathrm{mg} / \mathrm{L}$; the value of the rejection coefficient after $60 \mathrm{~min}$ of operation was $96.8 \%$; 3) it is worth mentioning that the mean remaining oil concentration for the zeolite membrane (ZMDC) was well below the mean remaining concentration of the oil for ceramic membrane, being this reduction from 15 to $3.2 \mathrm{mg} / \mathrm{L}$; this reduction is one of the advantages of the zeolite membrane; this was because the zeolite layer deposited on the surface of the ceramic membrane made the process more efficient due to its uniform pore size and molecular sieving; 4) analyzing the results of the rejection coefficient, the value for zeolite membrane (ZMDC) was $96.8 \%$ and for ceramic membrane was $88.0 \%$, showing a better performance for the zeolite membrane, since the value of the rejection coefficient was higher; 5) zeolite membrane ZMVPT: an initial reduction of the permeate oil concentration from 100 to $31 \mathrm{mg} / \mathrm{L}$ in the first $5 \mathrm{~min}$ of operation, then decreasing to $20 \mathrm{~min}$ and then remaining practically constant; the average remaining oil concentration was $3.5 \mathrm{mg} / \mathrm{L}$; the value of the rejection coefficient after 60 min of operation was $96.4 \%$ for the zeolite membrane; 6) the zeolite membranes showed improvements, since the value of the rejection coefficient was higher than the value found for the ceramic membrane; this fact evidenced the positive effect of the insertion of the MCM-22 zeolite layer on the ceramic membrane ( $\alpha$-alumina); and 7) the MCM-22 zeolite membranes (ZMDC and ZMVPT) presented final values of the permeate concentration of $3.2 \mathrm{mg} / \mathrm{L}$ which was within the standards required by Resolution No. 392 of CONAMA [72] which is up to $20 \mathrm{mg} / \mathrm{L}$ mineral oils.

Evaluation of the ceramic and used zeolite MCM-22 membranes ( $2^{\text {nd }}$ cycle): oil/water emulsion flow measurement tests were performed for a further cycle of $60 \mathrm{~min}$, called the $2^{\text {nd }}$ cycle. Simple cleaning was performed as described in the experimental section. After cleaning, these membranes were again reused in order to verify their chemical and mechanical stability, comparing the new flows with those already measured previously, in addition to the rejection coefficient. According to [73], membrane cleaning is an essential step in maintaining the permeability and selectivity of the membrane technology process. Figs. 5c and 5d show the measurements of oil content in the permeate and rejection coefficient as 
Table II - Comparison of permeate flux and rejection data for separation of the oil-in-water emulsion of the present study with other membranes published in the literature.

[Tabela II - Comparação dos dados de fluxos permeados e coeficiente de rejeição para separação emulsão óleo/água do presente estudo com outras membranas publicados na literatura.]

\begin{tabular}{|c|c|c|c|c|c|}
\hline Membrane & $\begin{array}{l}\text { Method of } \\
\text { preparation }\end{array}$ & Parameters & $\begin{array}{c}\text { Flow } \\
\left(\mathrm{L} \cdot \mathrm{m}^{-2} \cdot \mathrm{h}^{-1}\right)\end{array}$ & $\begin{array}{l}\text { Coefficient of } \\
\text { rejection }(\%)\end{array}$ & Ref. \\
\hline $\begin{array}{c}\text { Zeolite } \\
\text { (MCM-22/ } \alpha \text {-alumina) } \\
\text { ZMDC }\end{array}$ & $\begin{array}{l}\text { Dip coating: } \\
150{ }^{\circ} \mathrm{C}, 10 \text { days }\end{array}$ & $\begin{array}{c}\text { Synthetic oil, } \mathrm{C}_{\mathrm{f}}=100 \mathrm{mg} / \mathrm{L}, \\
\mathrm{C}_{\mathrm{p}}=3.21 \mathrm{mg} / \mathrm{L}, \text { pressure }=2.0 \mathrm{bar}, \\
\text { temp }=25^{\circ} \mathrm{C}, 1^{\text {st }} \text { cycle }\end{array}$ & 696 & 96.8 & $\begin{array}{l}\text { This } \\
\text { study }\end{array}$ \\
\hline $\begin{array}{c}\text { Zeolite } \\
\text { (MCM-22/ } \alpha \text {-alumina) } \\
\text { ZMDC }\end{array}$ & $\begin{array}{l}\text { Dip coating: } \\
150^{\circ} \mathrm{C}, 10 \text { days }\end{array}$ & $\begin{array}{l}\text { Synthetic oil, } \mathrm{C}_{\mathrm{f}}=100 \\
\mathrm{mg} / \mathrm{L}, \mathrm{C}_{\mathrm{p}}=3.21 \mathrm{mg} / \mathrm{L} \\
\text { pressure }=2.0 \mathrm{bar} \\
\text { temp. }=25^{\circ} \mathrm{C}, 2^{\text {nd }} \text { cycle }\end{array}$ & 674 & 95.8 & $\begin{array}{l}\text { This } \\
\text { study }\end{array}$ \\
\hline $\begin{array}{c}\text { Zeolite } \\
\text { (MCM-22/ } \alpha \text {-alumina) } \\
\text { ZMVPT }\end{array}$ & $\begin{array}{l}\text { Vapor phase } \\
\text { transport: } \\
150^{\circ} \mathrm{C}, 10 \text { days }\end{array}$ & $\begin{array}{c}\text { Synthetic oil, } \mathrm{C}_{\mathrm{f}}=100 \mathrm{mg} / \mathrm{L}, \\
\mathrm{C}_{\mathrm{p}}=3.98 \mathrm{mg} / \mathrm{L}, \text { pressure }=2.0 \text { bar, } \\
\text { temp }=25^{\circ} \mathrm{C}, 1^{\text {st }} \text { cycle }\end{array}$ & 721 & 96.4 & $\begin{array}{l}\text { This } \\
\text { study }\end{array}$ \\
\hline $\begin{array}{c}\text { Zeolite } \\
\text { (MCM-22/ } \alpha \text {-alumina) } \\
\text { ZMVPT }\end{array}$ & $\begin{array}{l}\text { Vapor phase } \\
\text { transport: } \\
150^{\circ} \mathrm{C}, 10 \text { days }\end{array}$ & $\begin{array}{c}\text { Synthetic oil, } \mathrm{C}_{\mathrm{f}}=100 \mathrm{mg} / \mathrm{L}, \\
\mathrm{C}_{\mathrm{p}}=3.57 \mathrm{mg} / \mathrm{L}, \text { pressure }=2.0 \mathrm{bar}, \\
\text { temp }=25^{\circ} \mathrm{C}, 2^{\text {nd }} \text { cycle }\end{array}$ & 708 & 96.0 & $\begin{array}{l}\text { This } \\
\text { study }\end{array}$ \\
\hline Zeolite (Y/ $\gamma$-alumina) & $\begin{array}{l}\text { Dip coating: } \\
90^{\circ} \mathrm{C}, 7 \mathrm{~h}\end{array}$ & $\begin{array}{c}\text { Synthetic oily wastewater, } \\
\mathrm{C}_{\mathrm{f}}=500 \mathrm{mg} / \mathrm{L}, \mathrm{C}_{\mathrm{p}}=50 \mathrm{mg} / \mathrm{L}, \\
\text { pressure }=1.0 \text { bar, temp. }=25^{\circ} \mathrm{C}\end{array}$ & 565 & 90.0 & [51] \\
\hline Zeolite (Y/ $\alpha$-alumina) & $\begin{array}{l}\text { Dip coating: } \\
90^{\circ} \mathrm{C}, 7 \mathrm{~h}\end{array}$ & $\begin{array}{c}\text { Synthetic oily wastewater, } \\
\mathrm{C}_{\mathrm{f}}=500 \mathrm{mg} / \mathrm{L}, \mathrm{C}_{\mathrm{p}}=33 \mathrm{mg} / \mathrm{L}, \\
\text { pressure }=1.0 \text { bar, temp. }=25^{\circ} \mathrm{C}\end{array}$ & 875 & 93.4 & [51] \\
\hline $\begin{array}{c}\text { Zeolite } \\
\text { (NaY } / \gamma \text {-alumina) }\end{array}$ & $\begin{array}{l}\text { Rubbing: } \\
90^{\circ} \mathrm{C}, 7 \mathrm{~h}\end{array}$ & $\begin{array}{c}\text { Synthetic oily wastewater, } \\
\mathrm{C}_{\mathrm{f}}=100 \mathrm{mg} / \mathrm{L}, \mathrm{C}_{\mathrm{p}}=4.7 \mathrm{mg} / \mathrm{L}, \\
\text { pressure }=2.0 \text { bar, temp. }=25^{\circ} \mathrm{C}\end{array}$ & 746 & 95.2 & [52] \\
\hline $\begin{array}{c}\text { Zeolite } \\
\text { (NaY/ } \alpha \text {-alumina) }\end{array}$ & $\begin{array}{l}\text { Rubbing: } \\
90^{\circ} \mathrm{C}, 7 \mathrm{~h}\end{array}$ & $\begin{array}{c}\text { Synthetic oily wastewater, } \\
\mathrm{C}_{\mathrm{f}}=100 \mathrm{mg} / \mathrm{L}, \mathrm{C}_{\mathrm{p}}=1.3 \mathrm{mg} / \mathrm{L} \\
\text { pressure }=2.0 \mathrm{bar}, \text { temp. }=25^{\circ} \mathrm{C}\end{array}$ & 1036 & 98.7 & [52] \\
\hline
\end{tabular}

a function of time for the $2^{\text {nd }}$ cycle obtained with oil/water emulsion, according to the system presented in Fig. 1. As can be seen, when reused, the membranes had practically the same permeate fluxes. The membrane cleaning process had a satisfactory effect on the oil/water emulsion permeation performance of the membranes, resulting in an initial flow recovery of $99.0 \%$, that is, the option of using this organic scale reduction strategy (backwashing) was efficient.

Table II shows permeate flow and rejection coefficient data of the present study and some data presented in the literature. The zeolite membranes produced in this study (ZMDC and ZMVPT) presented satisfactory results when compared with the results found in the literature [5059]. The results found for the zeolite membranes MCM22 independent of the method used, dip coating or vapor transport, were similar, evidencing that the production method had no influence on the results. However, there were differences between the two methods of preparation. The dip coating method had an advantage in terms of reproducibility, while the steam transport method had advantages in the ability to control the zeolitic layer on the support (alumina), the minimization of waste, and the reduced consumption of chemical reagents.

\section{CONCLUSIONS}

The dip coating and vapor-phase transport methods may be recommended as promising for the preparation of zeolite membranes of the MCM-22 type. Zeolite membranes were able to produce a permeate stream with oil content in the range of 3.2 to $3.9 \mathrm{mg} / \mathrm{L}$, complying with the requirements established by Resolution No. 392 of CONAMA, and with potential for the treatment of wastewater contaminated by oily effluents.

\section{ACKNOWLEDGMENT}

The authors thank CAPES (Coordenação de Aperfeiçoamento de Pessoal de Nível Superior).

\section{REFERENCES}

[1] P.S. Goh, C.S. Ong, B.C. Ng, A.F. Ismail, in Nanotechnol. Water Wastewater Treat., Elsevier (2019) 101. 
[2] L. Yu, M. Han, F. He, Arab. J. Chem. 10 (2017) 1913. [3] S. Huang, H.A. Robin, R.X. Tian, Curr. Opin. Colloid Interface Sci. 36 (2018) 90.

[4] A.J. Burggraaf, L. Cot, Fundamentals of inorganic membrane science and technology, Elsevier, Amsterdam (1996).

[5] R. Rautenbach, R. Albrecht, Membrane processes, John Wiley Sons, New York (1989).

[6] R. Ghosh, in Ency. membr. sci. technol., E.M.V. Hoeck, V.V. Tarabara (Eds.), John Wiley Sons (2013).

[7] S. Aguado, J. Gascón, J.C. Jansen, F. Kapteijn, Micropor. Mesopor. Mater. 120 (2009) 170.

[8] A. Huang, N. Wang, J. Caro, J. Membr. Sci. 389 (2012) 272.

[9] D.A. Fedosov, A.V. Smirnov, V.V. Shkirskiy, T. Voskoboynikov, I.I. Ivanova, J. Membr. Sci. 486 (2015) 189. [10] L. Cot, A. Ayral, J. Durand, C. Guizard, N. Hovnanian, A. Julbe, Solid States Sci. 2 (2000) 313.

[11] G. Busca, in Adv. Catalysis 57, Elsevier (2014).

[12] N. Rangnekar, N. Mittal, B. Elyassi, J. Caro, M. Tsapatsis, Chem. Soc. Rev. 44 (2015) 7128.

[13] M. Matsuda, in Nanopart. technol. handb., $3^{\text {rd }}$ ed., Elsevier (2018) 539.

[14] A. Julbe, Stud. Surf. Sci. Catal. 168 (2007) 181.

[15] J. Caro, in Zeolites zeolite-like mater., Elsevier (2016) 283.

[16] R. Dragomirova, S. Wohlrab, Catalysts 5 (2015) 2161.

[17] C. Pagis, A.R.M. Prates, D. Farrusseng, N. Bats, A. Tuel, Chem. Mater. 28 (2016) 5205.

[18] S. Daer, J. Kharraz, A. Giwa, S.W. Hasan, Desalination 367 (2015) 37.

[19] J. Caro, M. Noack, Micropor. Mesopor. Mater. 115 (2008) 215.

[20] J. Caro, M. Noack, P. Kölsch, Adsorption 11 (2005) 215.

[21] J. Caro, M. Noack, P. Kölsch, R. Schäfer, Micropor. Mesopor. Mater. 38 (2000) 3.

[22] N. Rangnekar, N. Mittal, B. Elyassi, J. Caro, M. Tsapatsis, Chem. Soc. Rev. 44 (2015) 7128.

[23] R. Zhou, L. Hu, Y. Zhang, N. Hu, X. Chen, X. Lin, H. Kita, Micropor. Mesopor. Mater. 174 (2013) 81.

[24] C. Zhang, Z. Hong, J. Chen, X. Gu, W. Jin, N. Xu, J. Membr. Sci. 389 (2012) 451.

[25] W. Xiao, Z. Chen, L. Zhou, J. Yang, J. Lu, J. Wang, Micropor. Mesopor. Mater. 142 (2011) 154.

[26] Y. He, X. Cui, X. Liu, Y. Wang, J. Zhang, K. Liu, J. Membr. Sci. 447 (2013) 66.

[27] F. Guillou, L. Rouleau, G. Pirngruber, V. Valtchev, Micropor. Mesopor. Mater. 119 (2009) 1.

[28] S.K. Seshadri, Y.S. Lin, Sep. Purif. Technol. 76 (2011) 261.

[29] C. Algieri, P. Bernardo, G. Barbieri, E. Drioli, Micropor. Mesopor. Mater. 119 (2009) 129.

[30] I. Tiscornia, I. Kumakiri, R. Bredesen, C. Téllez, J. Coronas, Sep. Purif. Technol. 73 (2010) 8.

[31] N.O. Chisholm, G.C. Anderson, J.F. Mcnally, H.H. Funke, R.D. Noble, J.L. Falconer, J. Membr. Sci. 493 (2015) 206.
[32] K.D. Pierotti, D.J. St. Julien, "Zeolite membrane and a process for the production thereof", U.S. Patent $6,440,885$ B1 (2002).

[33] F. Akhtar, E. Sjöberg, D. Korelskiy, M. Rayson, J. Hedlund, L. Bergström, J. Membr. Sci. 493 (2015) 206.

[34] A. Huang, Q. Liu, N. Wang, X. Tong, B. Huang, M. Wang, J. Caro, J. Membr. Sci. 437 (2013) 57.

[35] B. Soydaş, Ö. Dede, A. Çulfaz, H. Kalipçilar, Micropor. Mesopor. Mater. 127 (2010) 96.

[36] F. Gallucci, in Methanol, Elsevier (2018) 493.

[37] C. Perego, R. Bagatin, M. Tagliabue, R. Vignola, Micropor. Mesopor. Mater. 166 (2013) 37.

[38] S. Auerbach, K. Carrado, P. Dutta (Eds.), Handb. zeolite sci. tecnol., Marcel Dekker, New York (2003).

[39] C. Algieri, P. Bernardo, G. Barbieri, E. Drioli, Micropor. Mesopor. Mater. 119 (2009) 129.

[40] S.P. Nunes, Membr. Sci. Technol. 13 (2008) 121.

[41] R. Liu, S. Dangwal, I. Shaik, C. Aichele, S. Kim, Sep. Purif. Technol. 195 (2018) 163.

[42] C. Delitala, E. Cadoni, D. Delpiano, D. Meloni, S. Melis, I. Ferino, Micropor. Mesopor. Mater. 110 (2008) 197. [43] G. Berlier, M. Pourny, S. Bordiga, G. Spoto, A. Zecchina, C. Lamberti, J. Catal. 229 (2005) 45.

[44] A. Albuquerque, L. Marchese, L. Lisi, H.O. Pastore, J. Catal. 241 (2006) 367.

[45] J. Aguilar, S.B.C. Pergher, C. Detoni, A. Corma, F.V. Melo, E. Sastre, Catal. Today 133-135 (2008) 667.

[46] R.M. Mihályi, K. Lázar, M. Kollár, F. Lónyi, G. PálBorbély, Á. Szegedi, Micropor. Mesopor. Mater. 110 (2008) 51.

[47] S. Choi, J. Coronas, Z. Lai, D. Yust, F. Onorato, M. Tsapatsis, J. Membr. Sci. 316 (2008) 145.

[48] J. Rigoreau, S. Laforge, N.S. Gnep, M. Guisnet, J. Catal. 236 (2005) 45.

[49] Q. Wen, J. Di, L. Jiang, J. Yu, R. Xu, Chem. Sci. 4 (2013) 591.

[50] A.S. Barbosa, A.S. Barbosa, M.G.F. Rodrigues, Mater. Sci. Forum (2019) in press.

[51] A.S. Barbosa, A.S. Barbosa, M.G.F. Rodrigues, Mater. Sci. Forum 912 (2018) 12.

[52] A.S. Barbosa, A.S. Barbosa, T.L.A. Barbosa, M.G.F. Rodrigues, Sep. Purif. Technol. 200 (2018) 141.

[53] F.N.M. Silva, "Síntese de membranas zeolíticas (mordenita/ $\alpha$-alumina) utilizando os métodos de síntese hidrotérmica, dip-coating e transporte em fase vapor e avaliação na separação emulsão óleo/água", Tese Dr., Un. Fed. Campina Grande (2018).

[54] F.M.N. Silva, E.G. Lima, T.L.A. Barbosa, M.G.F. Rodrigues, in $13^{\text {th }}$ Int. Conf. Catal. Membr. React., Houston (2017).

[55] A.S. Barbosa, A.S. Barbosa, T.L.A. Barbosa, M.G.F. Rodrigues, in $13^{\text {th }}$ Int. Conf. Catal. Membr. React., Houston (2017).

[56] A.S. Barbosa, "Preparação de membranas zeolíticas (Y/gama-alumina) utilizando diferentes métodos visando sua aplicação no processo de separação emulsão óleo/água", Tese Dr., Un. Fed. Campina Grande (2015). 
[57] M.G.F. Rodrigues, A.S. Barbosa, A.C.F. Coriolano, E.F.B. Silva, A.S. Araujo, Mater. Sci. Poland 33, 1 (2015) 131.

[58] A.S. Barbosa,A.S. Barbosa, M.G.F. Rodrigues, Desalin. Water Treat. 1 (2015) 1.

[59] F.M.N. Silva, T.L.A. Barbosa, M.G.F. Rodrigues, in $12^{\text {th }}$ Int. Conf. Catal. Membr. React., Szczecin (2015).

[60] J.R. Scheibler, E.R.F. Santos, A.S. Barbosa, M.G.F. Rodrigues, Desalin. Water Treat. 1 (2014) 1.

[61] F.M.N. Silva, E.R.F. Santos, M.G.F. Rodrigues, in IX Ibero-Am. Congr. Membr. Sci. Technol., Santander (2014). [62] A.S. Barbosa, A.S. Barbosa, M.G.F. Rodrigues, Mater. Sci. Forum 805 (2014) 272.

[63] A.P. Araújo, M.G.F. Rodrigues, Adv. Cie. Ing. 3 (2012) 51.

[64] A.P. Araújo, V.J. Silva, A.C. Crispim, R.R. Menezes, M.G.F. Rodrigues, Mater. Sci. Forum 660-661 (2010) 1058. [65] R.C.N. Leite, B.V. Sousa, M.G.F. Rodrigues, Braz. J.
Pet. Gas 3 (2009) 75.

[66] S.B. Henderson, S.J.W. Grigson, P.E. Johnson, B.D. Roddie, Mar. Pollut. Bull. 38 (1999) 1141.

[67] F.D.S. Curbelo, A.I.C. Garnica, T.N.C. Dantas, E.L. Barros Neto, Braz. J. Pet. Gas 2 (2008) 46.

[68] R.C.N. Leite, B.V. Sousa, M.G.F. Rodrigues, Braz. J. Pet. Gas 3 (2009) 75.

[69] A.S. Barbosa, M.G.F. Rodrigues, in Congr. Bras. Catál. 1, Campos do Jordão (2011) 46.

[70] E. Jakobs, W.J. Koros. J. Membr. Sci. 124 (1997) 149.

[71] A. Hernández, J.I. Calvo, P. Prádanos, F. Tejerina, J. Membr. Sci. 112 (1996) 1.

[72] CONAMA, Resol. n 392, "Dispõe sobre o descarte contínuo de água de processo ou de produção em plataformas marítimas de petróleo e gás natural, e dá outras providências", DOU, Brasília (2007).

[73] S. Zhai, W. Zhang, T. Li, W. Zhang, L. Lv, B. Pan, Chemosphere 211 (2018) 139.

(Rec. 21/11/2018, Rev. 18/02/2019, Ac. 29/04/2019) 